\title{
Education of a Child in the Ethics of Al-Ghazali
}

\author{
M Sh Fayzullaeva* \\ Tajik State University of Law, Business and Politics (TSULBP), Tajikistan \\ *Corresponding author: M Sh Fayzullaeva, Tajik State University of Law, Business and Politics (TSULBP), Tajikistan
}

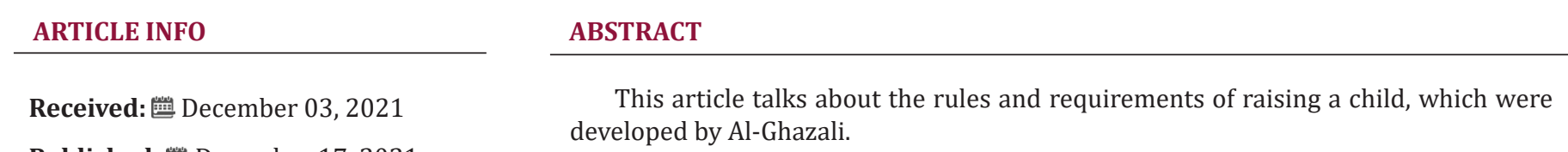

Published: 跳 December 17, 2021

Keywords: Family; Parents; Child; Upbringing; Decency; Kind Character

Citation: M Sh Fayzullaeva. Education of a Child in the Ethics of Al-Ghazali. Biomed J Sci \& Tech Res 40(4)-2021. BJSTR. MS.ID.006480.

\section{Opinion}

Muhammad al-Ghazali (1059-1111) in his ethical system, also expressed an opinion about the upbringing of children. He calls the child "enlightened, consanguineous, a continuation of life and the most precious gift of life". He says to the parent: "Know that the child is amanat (i.e. not property, but a temporary given from God) in the hands of the parents. The heart of a child is as pure as the earth, and every seed that you sow in it sprouts. The heart of a child is as delicate as pearls and as white as paper, and what you draw in it remains firmly in it.

Indeed, the birth of a child is the best gift of life for parents, happiness in the family, the fruit of love between husband and wife, which strengthens the union of spouses. Al-Ghazali mentions that the parents are the mentors of the child. The goal of upbringing is to get rid of a bad character trait. Therefore, parents should feel the bad quality of their child. In raising a child, parents are like a source of water, if the water is clean, then downstream it will be clean; raising children depends more on the mother than on the father. He advises parents to start raising their children from an early age since a child up to a certain age is easier to learn some of the pillars of morals. The child must first be taught to respect adults, develop a sense of hard work, and also need to warn about good and evil. Parents should treat their children politely, teach them to be kind and protect them from evil, because evil arises from the proximity of evil [1-6].

Parents should develop a spirit of mutual respect in the child, and the child should be taught the following rules of behavior: do not clean your mouth and nose in front of others, do not turn your back to people, and behave politely with people, do not put your hands under your jaw, which is a sign of laziness, does not pronounce oath, not to say too much, you need to speak only when asked, keep your tongue from abuse and curse, respect each younger, not be proud and brag to the children. In raising a child, it is appropriate to take the middle position. An overly serious attitude can lead to despondency, alienation, or, conversely, too much affection arises in the child of excessive laziness and selfishness. The child should not be severely punished, as he develops feelings of fear and hatred. For this reason, Al-Ghazali recommends praising a child for his good behavior in order to increase his (or her) interest in godliness. He says that if a child does a good deed and a good disposition has arisen in him, he must be given something as a gift to make him happy, and for this, he must be praised in front of others. Al-Ghazali recommends that parents teach boys and girls a certain profession before marriage and not force them to choose a spouse. Should not choose a bride or groom from an immoral family, the consequences of which will be devastating. 
Of course, raising a child is not an easy task. However, the scientist emphasizes that raising children should not be the reason for not generosity and indifference of parents to others. The purpose of starting a family is to bring up a healthy generation. The upbringing of society begins in the family. Raising a child is a serious responsibility that every parent must be aware of and fulfill. Parents should be the support and guardians of their children and should do everything possible for their peace of mind, happiness and full development. Parents, raising their children, pay back their duty to their parents. Indeed, the precious heritage of parents for a child is a good upbringing. The ethical conclusions of Muhammad Al-Ghazali on the sphere of raising children are attractive, in which the ways and methods of upbringing are shown in detail. The

\section{ISSN: 2574-1241}

DOI: $10.26717 /$ BJSTR.2021.40.006480

M Sh Fayzullaeva. Biomed J Sci \& Tech Res

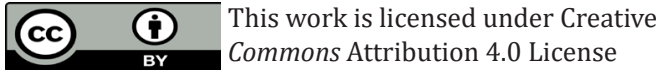

Submission Link: https://biomedres.us/submit-manuscript.php scientist's ethical teachings can be used as a guide by educators, psychologists and the general public.

\section{References}

1. Koran Trans Arabic Krachkovskiy I U.

2. Abuhamid Ghazali (2011) Nasihat-ul-muluk. -Dushanbe: Irfon.

3. Abuhamid Ghazali (2006) Research innermost secrets of the heart. / Trans. Arabic A. Miniyanova.-Moscow:Ansar.

4. Abuhamid Ghazali (2005) Alchemy of Happiness. /Kimei Saodat / Tashkent: Adolat.

5. Abuhamid Ghazali (2002) Mukoshafat-ul-Kulub. / Trans. Arabic Miraziz Azam. - Tashkent: Adolat.

6. Abuhamid Ghazali (2005) 0 son. / Trans. Yuldosh Eshbek.-Tashkent: Movarouhhahr.

$\begin{array}{ll}\text { BIOMEDICAL } & \text { Assets of Publishing with us } \\ \text { RESEARCHES } & \text { - Global archiving of articles } \\ \text { - Immediate, unrestricted online access }\end{array}$

